\title{
カルロス・フエンテス『アウラ』にみる 幻想性のモチーブ*
}

成田 瑞穂

\section{はじめに}

メキシコの作家カルロス・フエンテス（1928-）は多くの小説作品を発表す る一方で、文学および創作に関する評論も著し、小説を書くことや小説家であ ることの意味について積極的に発言している。そのなかでフエンテスは、小説 家の役割のひとつとして、知覚できる現実に平行する、もうひとつの現実 ${ }^{1)}$ 描くことがあると繰り返し述べている。フエンテスの短篇・中篇小説作品を概 観すると、ここで指摘される「もうひとつの現実を描く」手法には、日常的な 現実と幻想的なものが混合する世界を提示することがあるのが分かる。

本稿ではフエンテスの描く幻想世界に着目し、それがどのようなモチーフに よって提示されているか考察したい。本稿で中心的に扱う中篇『アウラ』 Aura（1962）の梗概は以下のとおりである。

若い歴史家を自認しているメキシコ人青年フェリーペ・モンテーロは、自分 に向けられたとしか考えられない新聞の求人広告に応え、年老いた未亡人コン スエロの夫で、メキシコ皇帝マクシミリアンの参謀であったというリョレンテ 将軍の回想録を整理、編纂する住み込みの仕事に就くことを決める。風通しが 悪く日差しも届かないコンスエロ夫人の屋敷の暗い雲囲気に飲み込まれそうに なりながら、フェリーペはコンスエロの姪であるアウラと愛し合い、ともに外 の世界へ逃げ出そうと考え始める。その一方で、単に伯母と姪というには、あ まりにも強い結びつきが感じられる、コンスエロとアウラの関係について、ど うにか論理的な説明を見いだそうとする。しかしリョレンテ将軍の回想録に綴 られた、コンスエロ夫人の子どもを生むことへの渴望、さらに若さに対する強 迫観念を読んでいくうち、フェリーペはアウラがこの未亡人の投影であること に気づく。そしてフェリーペの腕に抱かれたアウラは老婆コンスエロへと姿を 
変え、フェリーペ自身もリヨレンテ将軍へと変容し、若さと美の象徴である 「アウラ」を再び生み出すため、コンスエロと結ばれることになる。

『アウラ』ではコンスエロ夫人宅という幽冥の世界でフェリーペが体験する 3 日間の出来事が語られるが、それはフェリーペがリョレンテ将軍へ変容して いく過程を描いたものととらえることができる。この作品はオクタビオ・パス が中篇『誕生日』とともに「不気味で完璧な作品」) (Paz 1990: 7) であると評 し、また、「すべての一文一句に物語の展開上重要な役割がある」(安藤1982： 218）という指摘にもみられるように、研究者にとっては考察のポイントがち りばめられている。そこで、この『アウラ』とその他の短篇・中篇小説にも共 通する幾つかのモチーフを検討することで、フエンテス作品の持つ幻想性を明 らかにしたい。

\section{1. 異界への侵入}

幻想文学に関する入門書であるスタインメッツの『幻想小説』には、ピエー ル =ジョルジュ・カステックス、ロジェ・カイヨワ、ツベタン・トドロフによ る「幻想」の定義がまとめられている ${ }^{3)}$ 。それによるとカステックス、カイヨ ワはテキスト内に生起する神秘あるいは超自然的事象そのものに焦点を当て、 トドロフはその事象を受容する態度に着目するという違いがあるものの、3 者 とも現実／神秘、自然／超自然という、異質な世界の差異を想定している。こ の点から『アウラ』を読んでみると、この作品においても物語の冒頭部分で日 常と非日常という異なる世界の対比がかなり強調して描かれていることに気づ く。まず、フェリーペが「若い歴史家」を求める募集広告を見つけ、実際に指 定された場所を訪れるまでの描写は、この主人公の詳細な人物像が語られ、か れが平凡な日常を送っていることや、募集広告がまさに自分に宛てられている と感じながらも、その場所へ赴くことを逡巡する様子が語られる。このあたり は、全知の語り手が登場人物の行動や感情を読者に開陳するという意味で、伝 統的なリアリズムの手法を借用しているととらえることもできる ${ }^{4)}$ 。そしてフ エリーペがコンスエロ夫人宅へ足を踏み入れる場面で、語り手はかれが入って いこうとするその屋敷が、まるで別の世界であるかのように描写する。

ドアは君の指が軽く押しただけで開いてしまう。中に入る前に、最後に君 は肩越しに後ろを見る。(中略) いつもと変わらない、その外の世界のイ 
メージをひとつだけでも記憶に留めておこうとするが、うまくいかない5 (Fuentes 1990: 127)

『アウラ』の語り手は、フェリーペがコンスエロ夫人の家に入ろうとすると き、「最後に」とこの先二度と元の世界には戻らないこと示唆し、さらにかつ て生活していた世界の記憶を留めておくことすらできないと語りかける。そし て実際に、このときから物語末尾まで、フェリーぺは屋敷の外へ出ることはな い。そうしてかれが足を踏み入れた世界は、暗闇に覆われているため視覚以外 の感覚器官で認識したもの、例えば腐った木のにおい、ウサギに触れたときの 柔らかな感触などが語られてゆく。さらにその暗闇のなかでは具体的な時刻を 知ることも不可能になる。日差しが入らないため太陽や影の動きで時刻を知る ことができず、それに不安を覚えるフェリーぺは、時刻を気にしているかのよ うに、何度も自分の時計を確認する。そしてその後時刻の区切りは、アウラが 食事を知らせる鐘の音によって明らかになるだけとなり、最終的に物語の語り 手は、時計によって刻まれる時間がまやかしのものであるとフェリーペに告げ る。

君は時計に二度と目を向けないだろう。人間の虚栄心に合わせて偽りの時 間を計るその代物を、本物の時間を欺くために作り上げられた長い時間 を、ただ退屈に刻むその針を見ることはないだろう。本物の時間は、嘲る ように猛烈な速度で駆け抜けていき、どんな時計でも計ることなどできな いのだ' (Fuentes 1990: 157)

ここで述べられている、時計では計ることのできない本物の時間とは何を指 すのか、という点については、フエンテスの持つ時間概念とともに第 4 章で取 り上げる。ここでは、フェリーペが足を踏み入れた世界では時計によって示さ れる時間が無化されていることに着目したい。

時間が無化された異界への侵入というモチーフは『アウラ』の母胎となった 作品と考えられる短篇「トラクトカツィーネ、フランドルの庭からきた男」 Tlactocatzine, del jardín de Flandes (『仮面の日々』Los días enmascarados, 1954）にも見ることができる。この作品は、友人に頼まれ古い邸宅で留守番 をすることになった語り手の日記で構成されているが、その邸宅には現代のメ キシコシティと19世紀のフランドルという異なる時空間を繋ぐ矩形の庭があ 
る。この庭には、日暮れになるとメキシコ皇帝マクシミリアンの妻カルロタが 老婆の姿で語り手の前に現れる。語り手の男性にとってこの庭はそれまでの生 活とは異質のものであり、「邸宅内部に入ることで別世界の表皮に触れたのだ とすれば、この庭ではその神経にまで達したように思えた」 ${ }^{7}$ (Fuentes 1982: 38）と日記に記している。また、霧雨をもたらす雲に覆われ、見慣れ植物の 茂るこの場所はフランドルの画家メムリングの描く庭、「創り上げられた架空 の風景、メキシコにはない」 $\rfloor^{8)}$ (Fuentes 1982: 39) ものであり、さらに、決して 止むことのない霧雨は、この場所では天候の変化をもたらす時間の流れが停止 していることを示している。

また短篇集『不安な仲間』Inquieta compañía（2004）に収録され、『アウ ラ』を想起させるとの評価がある ${ }^{9)}$ 「良き仲間」La buena compañía は、パリ で生まれ育ったメキシコ人青年が、メキシコシティに住む伯母 2 人を訪ねると いう構成であり、主人公アレハンドロが初めて足を踏み入れるメキシコシティ という町、そして下宿先である伯母たちの屋敷は、どちらもかれにとって異質 な世界として示されている。

パリの完璧なシンメトリーをなした区画に慣れているので、アレハンドロ はメキシコシティという混沌とした都市を眺めると、まず困惑し、すぐに いやな気分になり、結局は魅了された。この町は抑制の効かないまま勢い に身を任せて当て所なく広がり、無限そのものに対し闘いを挑んでいるよ うに見えた ${ }^{10)}$ (Fuentes 2004: 87)

リベラ・デ・サン・コスメの家に 1 日居ただけで想像力が臨界を超えるの には十分で、自問せずにはいられなかった。ここはどこだ、この家には何 があるんた、正常、秘密、恐れ、神秘、ぼくの見ている幻覚、それともぼ くの理性では理解できないレベルの論理なのだろうか ${ }^{11}$ (Fuentes 2004: 97)

さらに、物語内では時刻を示す描写（アレハンドロが時計を確認する、伯母 たちの生活リズムが時刻によって指定されている）が多く見られるものの、そ れはむしろ伯母たちの屋敷では15年前から時間が流れていないことを際立たせ るためにある。アレハンドロが使う部屋には15年前のカレンダーがかけられて おり、さらにかれは、幼い頃の自分が15年前に書いたとされる架空の冊子『フ ランス少年のメキシコ冒険譚』を机の引き出しに見つけるのである。 
このように時間の流れが無化された世界のなかで、「トラクトカツィーネ」 に拈いては主人公の男性が皇帝マクシミリアンへ、「良き仲間」においてはア レハンドロが15年前に亡くなった子どもに寄り添う〈仲間〉へ変身することが 示唆されているが、その変身のあり様は『アウラ』ほど明確には述べられてい ない。その違いは何に起因するのだろうか。

\section{2. 性的な結びつきによる固有のアイデンティティの喪失}

『アウラ』では、時計によって示される時刻の概念が消滅した世界のなかで、 フェリーペがアウラと結ばれる。フエンテス作品においては、人物たちの性的 な結びつきにはセクシャルな意味だけではなく、当事者のアイデンティティの 問題が付随することが多くみられる。

オクタビオ・パスはフエンテスに大きな影響を与えたメキシコ論『孤独の迷 宮』El laberinto de la soledad（1950）に扔いて、「孤独とは、人間の条件の もっとも根底にあるもの。人間は自分がひとりだと感じる唯一の存在であり、 他者を求める唯一のものである。人間の本性とは（中略）他者の中に己を実現 しょうと切望することにある」 ${ }^{12)}(\mathrm{Paz}$ 1998: 341) と述べており、さらに『二重 の炎』La llama doble（1993）においては、その「已を実現しょうとする」試 みが性的な結びつきである場合には、その行為が一旦自己を失うことを意味す るとしている。

エロティックな出会いは求める肉体を目にすることで始まる。（中略）無 限という感覚。その肉体のなかでわたしたちは自分の肉体を失う。官能の 抱擁は、肉体の絶頂であり、肉体の衰失である。それは同時にアイデンテ イティを失う体験でもある。 ${ }^{13)}$ (Paz 1993: 204-205)

『アウラ』の場合、フェリーペはアウラとの性的な結びつきを体験する度に、 その自己の輪郭が曖昧になってゆく。それは例えば、初めてアウラと結ばれた 翌朝、フェリーペがいつもとは逆の順序で身支度をする様子が語られたり、次 章で触れるように、何度も鏡で自分の顔の確認をおこなっていることからも判 断できる。さらに物語末尾でかれは「27年間付けてきた仮面を見えない手に剥 がされてしまうのを恐れるかのように、自分の㚘骨や目、鼻を触って」 ${ }^{14)}$ (Fuentes 1990: 157) いる。つまり、かれはアウラとの性的な結びつきによっ てフェリーペとしての自己を失い、象徵的な死を体験し、それがリョレンテ将 
軍となって再生する契機になっているのである。

「トラクトカツィーネ」と「良き仲間」には見られない、性的な結びつきが 人物の輪郭を曖昧なものにするというモチーフが顕著に現れるのは、パスが 『アウラ』と並ぶ傑作と評した中篇『誕生日』Cumpleaños（1969）において である。この作品はイギリス人の建築家ジョージの夢という形式を用いつつ、 哲学、神話、宗教にまつわる様々なテーマが混在しており、フエンテス作品の なかでもひときわ難解なものとされている。この作品を読み解く方法のひとつ は、13世紀のイタリア、トラーニから現代のロンドンまでという異なる時空間 に偏在する女性ヌンシアが、繰り返し他の人物たちと性的な関係を持つ点に着 目することであろう。例えば、一人称で夢の内容を語るジョージは、ヌンシア との性交において、それを体験するのと同時にその交わりの様子を眺めてもい る。

私は自分の熱情に見とれている。背の高い安楽椅子に腰掛け、スッールに 足をのせたまま、ヌンシアを愛する自分を見ては喜び、欲情する。私はす べてを見ている。この目が嘘をつくことはない。私はヌンシアの身体に乗 りながら、自分が彼女を愛する様子を眺めている。ヌンシアは私の抱擁を 味わっている。これ以上確かな証拠などない。わたしは安楽椅子に腰掛 け、同時にベッドでヌンシアとともにいる自分を見ている。 ${ }^{15)}$ (Fuentes 1990: 200)

こののち一人称の語り手はジョージから、ふたりの性交を眺めていたもうひ とりの「私」へ移る。また、ヌンシアと再び結ばれることで、語り手は再びジ ヨージへ戻ったり、あるいはヌンシアと同化したり、さらには中世のスコラ哲 学者ブラバンティアのシゲルスへ変化したり、と自由に変容してゆく。パスは この物語に見られる人物間の流動性に着目し、「『誕生日』においてはアンデン ティティのテーマはいったん拡散しながら結合のテーマへ結びつき、結局は溶 解する」 ${ }^{16)}$ (Paz 1990: 14) と説明する。そしてその結果は「すべての人間であ るひとりの人間、すべての時間であるひとつの時間 ${ }^{17)}(\mathrm{Paz}$ 1990: 14) の表出 を示すことになるという。

『アウラ』の場合、『誕生日』とは異なり、フェリーペはすべての人間を包含 するような存在ではなく、リヨレンテ将軍という具体的なひとりの人物へと変 身する。そこで次章では、フェリーペによるリヨレンテ将軍への変容の過程を 
詳しく考察したい。

\section{3.「鏡」と「回想録」による自己の確認}

『アウラ』の物語が進んでいくにつれて（それは同時にフェリーペがアウラ との性交を重ねることを意味する)、段階的にフェリーペとしての存在が曖昧 になっていくことが分かる。それは、フェリーペ自身が屋敷に入った当日か ら、鏡に映した自らの顔の確認を何度もおこなっていることからも推察でき る。フェリーペはコンスエロ夫人の屋敷に行った当日、あてがわれた部屋の浴 室の鏡に自分の顔を映してみる。このときはまた、フェリーペは自分の顔を確 認することができているが、2 日目の晚にアウラとの性行為を体験したのち は、同じ鏡を預くものの、そこに映る自分の姿を認識できないかのように語ら れている。

この鏡のモチーフは、『アウラ』ほど明確ではないものの、先述した「良き 仲間」にも見ることができる。メキシコシティに到着したばかりのアレハンド ロは、伯母との食事の前に鏡を見ながら身支度を整える。しかし伯母たちの奇 妙な行動に耐えられなくなるころ、浴室の鏡が取り外され、自分の姿を確認で きないことに気づく。ただし、この作品ではアレハンドロの変身よりも、人物 として固有のアンデンティティの脆弱さを示すだけに留まっており、『アウラ』 におけるフェリーペとは対照的である。というのは、フェリーペはさらに次の 段階へと進むからである。

浴室の鏡で自己の確認ができなくなったフェリーペには、その代替として、 鏡のように新たな自己を映し出すものが用意されている。それがリョレンテ将 軍の回想録である。コンスエロ夫人はこの回想録を編纂して出版することを望 んでいるとフェリーペに告げ、「完成させなければならない」 ${ }^{18)}$ (Fuentes 1990: 130) と述べているが、これは未完になっている回想録に、フェリーペという、 のちにリョレンテ将軍として再生する若い男性の存在が欠けていることを示し ているのは明らかである。

この回想録はみっつの束に分けられ、コンスエロ夫人からフェリーペへ 1 日 にひとつずつ渡される。屋敷に到着した当日、ひとつ目の束が渡されるが、こ の部分にはリョレンテ将軍の生い立ちが綴られているだけで、フェリーペは興 味を持たない。また日記の内容は直接引用したものではなく、フェリーペ自身 が解釈、整理した形で現れるだけである。しかしアウラと初めて結ばれた後に 渡されたふたつ目の束には、リヨレンテ将軍による記述がそのまま抽出される 
形でフランス語が引用されている。そしてそのふたつ目の束で初めてフェリー ペは、リヨレンテ将軍とコンスエロ夫人の出会い、その後の結婚生活の様子を 知ることになる。若いコンスエロ夫人の美しさを讃える文章があり、フェリー ペは彼女の若さ、美しさへの執着と、現在の魔女的な存在を結びつけて考える ようになる。さらに、二度目にアウラと結ばれた後では、フェリーペは自らみ つつ目の束を盗み出して読むほどの焦りを見せている。みっつ目の束にはコン スエロが自分の分身を生み出そうとさまざまな魔術を駆使する様子と、それに 対するリヨレンテ将軍の諦観が語られているが、そこに引用されるリョレンテ 将軍の言葉はすでにフェリーペの声と一体化しており、スペイン語で綴られて いる。それはフェリーペがリョレンテ将軍という存在に同化あるいは変容しつ つあることが示されているのであろう。

このみっつ目の束に挟まれた写真で、アウラとはコンスエロの分身であり、 フェリーペがリョレンテ将軍であることが明らかになる。アウラとの性的な結 びつきにより自己を喪失したフェリーペが、新たな鏡として自己を映そうとす る回想録には、リョレンテ将軍の姿があった。つまりフェリーペにとって回想 録を読む行為は、自分が生まれ変わるリヨレンテ将軍の過去を知る作業であ り、同時にアウラとの交わりによって喪失した自己を確認するものなのであ る。そして、フェリーペの変容のすべてを語っているのが、かれに向かって 「君」と呼びかける二人称の語り手である。

\section{4. 二人称の語り手}

『アウラ』の手法としてもっとも特徵的であり、研究者たちが注目するのは 語り手の存在である。この語り手の声はいったい誰のものなのかという点につ いては発表当時より様々な視点から考察がなされてきた。特によく見られるの は、語り手はフェリーペ自身であり、二人称の語りを用いた内的独白の変形だ という論旨である ${ }^{19)}$ 。フェリーペが体験する出来事を、かれ自身の潜在意識が 描写していると解釈し、物語全体がフェリーペの抱く夢あるいは幻覚であっ て、この作品の登場人物はフェリーペただひとり、と結論づける研究者もい る ${ }^{20)}$ 。たしかに、二人称の語り手は、作品冒頭からフェリーペの知覚したもの だけを描写し、登場人物のなかではフェリーペの感情や思考だけを詳細に述べ ている。したがってこの語り手が、フェリーペと何らかの関わりのある存在で あることは確実であると考えられる。

一方で、もうひとりの登場人物であるコンスエロ夫人が語り手の声の主であ 
る、という意見もある ${ }^{21}$ 。それは物語世界でのフェリーペの行動がすべて、コ ンスエロ夫人に支配されていると考えられるからである。例えば暗い中庭に入 ったフェリーペは明かりを求めてマッチを擦ろうとするが、コンスエロ夫人の 声に止められ、彼女の声に導かれ階段を昇り、その寝室までたどり着く。同様 に薄暗いその部屋でも、フェリーペを導くのはコンスエロ夫人の声であり、常 に彼女が会話の主導権を握っている。仕事の条件はコンスエロ夫人宅でともに 生活することだと告げられ、迷うフェリーペにアウラを紹介し、受け入れを決 心させるのも彼女である。このようにコンスエロ夫人が、分身アウラを使って フェリーペの行動をコントロールしていることを考えれば、二人称の語り手が コンスエロ夫人であるという解釈も成り立つように思われる。しかし、物語冒 頭に描かれる、フェリーペが新聞広告を見つけ、その仕事を受けることを逡巡 する様子など、屋敷という異界へ入る以前、すなわちフェリーペが未だ理性的 な思考を維持している場面での、かれの心理描写が行われていたり、幻想的世 界へ引き达まれそうになる戸惑い、さらに自らそこへ入っていこうとする焦り も語られていたりすることを考慮すると、コンスエロ夫人が語り手の声の持ち 主という見解は少々強引さが否めない。

フェリーペの潜在意識、コンスエロ夫人に着目するどちらの見解も、語り手 は物語内に存在する人物で、作中の出来事を同時進行的に語る声を持つ、と解 棌している点では共通している ${ }^{22)}$ 。しかし語りの場というものを物語内、つま り語りの声の主を作中の出来事に関与する人物に限定せずに考えた場合、他の 可能性が見えてくる。さらに語り手が未来時制を多用していること、またフエ ンテスが自作に取り入れている時間概念にも注目したい。

フエンテスは『アウラ』、『誕生日』、遠い家族』Una familia lejana (1980)、 『コンスタンシア、処女のためのその他の小説』Constancia, otras novelas para vírgenes (1990) の 4 冊の書籍について、「(これらの作品によって) わ たしの抱いている時間概念が線的なものではない、ということを知って欲し い。それはときには円環的であり、ときには永劫回帰的であり、また螺旋的で もあるのだ。わたしの考える時間とは、現在のなかに過去を、そして未来を恒 久的に取り戻すことである」 に拈いて、フエンテスはフェリーペが自分の分身であるリョレンテ将軍の過去 を回想録として読む様子を描いた。そのすべては未来時制を多用する二人称の 語り手によって明らかにされている。

円環的・螺旋的であるフエンテスの時間概念から物語を眺めると、この二人 
称の語り手はフェリーペの体験を同時進行的に語る内的自己ではなく、かつて フェリーペであり、今は物語世界の枠外にいる存在が、これからリョレンテ将 軍への変容を遂げる別のフェリーペに語りかけている、という解釈が可能にな る。スペイン語の未来時制には命令の用法があることから、小説作品において この時制が使われる場合、バルガス・リヨサが指摘するように、語り手は圧倒 的優位に立ち、作中人物の逃れられない運命を示すことができる ${ }^{24)}$ 。そして 『アウラ』の語り手の場合、フェリーペの宿命を語るだけではなく、この語り 手がすべてを体験し、これからフェリーペが同じことを体験すると知っている からこそ、未来時制の語りになっているのであろう。さらに、物語世界のフェ リーペがリョレンテ将軍への変身を遂げた後には、物語の冒頭にあるように、 「君は広告に眼を留める」 ${ }^{25)}$ (Fuentes 1990: 125) と次のフェリーペに向かって 語りかけていくと考えられる。

フエンテスの考える円環的、螺旋的な時間概念は、『アウラ』において、二 人称の語り手が未来形を多用して語ることによって、顕在化している。それは フェリーペの 1 回限りの変身譚を提示するのではなく、フェリーペという存在 が、何度でも死と再生を繰り返す永続的な世界を示すものである。

線的時間を否定する作品としてフエンテスが挙げている 4 冊のうち語り手自 身の変異、および語りの場の永続という意味では『遠い家族』が『アウラ』と 共通していると言える。

この物語は友人であるブランリー伯爵の体験を本人から聞いている語り手 が、一人称でその内容を語るという形式を用いている。ブランリー伯爵が語る 体験とは、メキシコ人考古学者ウーゴ・エレディアとその息子が、自分たちの 同姓同名の人間を探すゲームに端を発する奇妙な出来事である。そこにはメキ シコとフランスの関係、虚構と現実、記憶と歴史、自己と他者の関わりという ようなテーマを見出すことができるが、特に強調されているのが、語るという 行為に永続性を付与しているという点である。

エレディアからブランリーへ、そして作品の語り手であるフエンテスという 名のメキシコ人男性へと、物語を聞いた人間が今度はそれを語る側に变わって いくという、螺旋的な構造をこの作品は備えているのである。物語末尾でブラ ンリーがフエンテスへ告げるように、小説とはすべて未完であり、他の小説と 隣接しながら続いていく ${ }^{26)}$ 。すなわちこの物語には確定した形での終焉がな く、語りを受け継いでゆく次の語り手によって別の物語が想起され、様々に異 なる、開かれた結末が提示される。 
『アウラ』がフェリーペからリョレンテ将軍への変容を無限に紡いでいく一 方で、『遠い家族』においては物語の結末が当て所なく拡散していくという違 いはあるものの、物語を展開する語り手の様々な形での変遷により、物語世界 が続いていくという共通点が見出せる。

\section{おわりに}

『アウラ』においてフエンテスは線的ではない時間概念が支配する異界を示 し、そのなかで人物の輪郭が曖昧になっていく様を、それによってもたらされ る焦燥感とともに描き出している。性的な結びつきによるフェリーペとしての 自己の象徵的な死と、鏡によってリョレンテ将軍として再生する変容が円環的 な構造にあることは、未来形動詞を多用する二人称の語り手という手法によっ て浮かび上がってくる。そしてこれらのモチーフがフエンテスの他の作品にも 共通することも指摘した。

フエンテスは1980年代以降、自分の作品群を 1 冊の長大な書籍と見なす、 『時の時代』La Edad del Tiempo ${ }^{27)}$ という名のプロジェクトを進めている。こ のプロジェクトにおいて、個々の作品は単独で、あるいはテーマごとに何冊か のグループで一つの章を構成している。これまで見て来た『アウラ』と共通す る幻想性のモチーフが見出せる作品は第 1 章と第10章に分かれているが、この リストの発表以降の動向を見るとこの二つの章の内容は入れ替わりがあり、流 動的である。いずれにしても、この二つの章に分類された作品が、フエンテス のいわゆる「幻想小説群」に当てはまると考えられる。

これら幻想小説群において、円環的あるいは螺旋的な時間概念を取り込むフ エンテスが描く物語世界は、日常とは異質な空間のなか、語り手や登場人物の さまざまな形での変容が提示され、真の終焉を拒むものであると言える。

\section{註}

* 本稿は日本イスパニヤ学会第55回大会（2009年10月11日、静岡県立大学）における 口頭発表に加筆修正をしたものである。貴重なご意見をいただいた方々に深い謝意 を表したい。

1) una segunda realidad, una realidad paralela (Fuentes 1969: 19) また、Fuentes 1993, Cruz 2008 などにおいても同様の発言が見られる。

本稿におけるスペイン語文献からの引用はすべて拙訳である。本文拉よび註には引 用文献の作者の姓、出版年、該当ページを記すに留め、該当する原文を註に記載す るとともに、完全な書誌情報は引用文献一覧に明記する。また、邦訳のあるものは 
参照させていただき、その書誌情報を資料文献一覧に明記する。

2) dos nouvelles macabras y perfectas.

3）スタインメッッのまとめた、三者による「幻想」の定義は以下のとおり。 (Steinmetz 1993: 17-21、カイヨワとトドロフの著作については、スタインメッッ が参照した原著の和訳が刊行されているので、該当ページをカッコ内に記す)

カステックス：現実の生活の枠組みのなかへの神秘の突然の侵入

カイ ヨワ：超自然が、世界の整合性を切断するものとして現れる (Caillois 1978: 10-11)

トドロ フ：自然の法則しか知らぬものが、超自然と思える出来事に直面して感 じる「ためらい」である (Todorov 1999: 42)

4）ただし、語り手が詳細に描写するのが、フェリーペの思考や感情だけであることも 特徵的である。この点については第 4 章にて考察する。

5) La puerta cede al empuje levísimo, de tus dedos, y antes de entrar miras por última vez sobre tu hombro, (...) Tratas, inútilmente, de retener una sola imagen de ese mundo exterior indiferenciado.

6) No volverás a mirar tu reloj, ese objeto inservible que mide falsamente un tiempo acordando a la vanidad humana, esas manecillas que marcan tediosamente las largas horas inventadas para engañar el verdadero tiempo, el tiempo que corre con la velocidad insultante, mortal, que ningún reloj puede medir.

7) Si ya en la casa rozaba la epidermis de otro mundo, en el jardín me pareció llegar a sus nervios.

8) Era un paisaje ficticio, inventado. ¡El jardín no estaba en México!

9) Long 2005 を参照。

10) Acostumbrado a la perfecta simetría del trazo parisino, el caos urbano del Distrito Federal lo confundió primero, lo disgustó enseguida, lo fascinó al cabo. México le pareció una ciudad sin rumbo, entregada a su propia velocidad, perdidos los frenos, dispuesta hacerle la competencia al infinito mismo.

11) Le bastó un día en la casa de la Ribera de San Cosme para que la imaginación diera el paso de más que nos obliga a preguntarnos ¿dónde estoy?, ¿qué hay en esta casa?, ¿normalidad, secreto, miedo, misterio, alucinaciones mías, razones que escapan a las mías?

12) La soledad es el fondo último de la condición humana. El hombre es el único ser que se siente solo y el único que es búsqueda de otro. Su naturaleza - consiste en un aspirar a realizarse en otro.

13) El encuentro erótico comienza con la visión del cuerpo deseado. - Sensación de infinitud: perdemos cuerpo en ese cuerpo. El abrazo carnal es el apogeo del 
cuerpo y la pérdida del cuerpo. También es la experiencia de la pérdida de la identidad.

14) te tocas los pómulos, los ojos, la nariz, como si temieras que una mano invisible te hubiese arrancado la máscara que has llevado durante veintisiete años.

15) Admiro mi propia pasión; sentado en el sillón de altas orejas, con los pies sobre el taburete, me veo amar a Nuncia, me congratulo, me excito. Todo lo estoy viendo; mis ojos no me mienten. Yo estoy encima de Nuncia, me veo amar a Nuncia, Nuncia goza en mis brazos. No puede haber prueba más eficaz: yo me estoy viendo, sentado desde mi sillón, en la cama con Nuncia.

16) el tema de la identidad que se dispersa se alía al de la unidad que se resuelve en disolución.

17) un hombre que es todos los hombres y un tiempo que es todos los tiempos.

18) deben ser completadas.

19）Durán 1976, Habra 2005 を参照。

20） Mead 1967 を参照。

21) Cano 1972 を参照。

22）フエンテス自身はこの語り手について、詩の世界では常套手段として使われてお り、それを小説が使用してはならないことはない、むしろ伝統的な手法だと述べて おり (Plimpton 1984: 357-358)、作者自身はこの手法の伝統的な意味、すなわち 読者と小説世界を結びつけることを念頭においていたようである。

23) Quiero dar a conocer que mi idea del tiempo no es lineal. En ocasiones se trata de una idea circular, en otras de un eterno retorno, en ocasiones de espirales. Mi tiempo constituye una recuperación constante del pasado en el presente y del futuro en el presente.

24) Vargas Llosa 1997: 80.

25) lees ese anuncio.

26) Fuentes 1994: 268.

27）下記リストを参照のこと。既刊作品には発行年を、本稿で取り上げた作品には* （アステリスク）を付記する。

Carlos Fuentes "La Edad del Tiempo"

(Fuentes 2009 および Carlos Fuentes official website から抜粋、編集)

\section{EL MAL DEL TIEMPO}

* Aura (1962)

* Cumpleaños (1969)

* Una familia lejana (1980)

2. TIEMPO DE FUNDACIONES 
Terra Nostra (1975)

El naranjo (1992)

3. EL TIEMPO ROMÁNTICO

La campaña (1990)

La novia muerta

El baile del Centenario

4. EL TIEMPO REVOLUCIONARIO

Gringo viejo (1985)

Emiliano en Chinameca

5. LA REGIÓN MÁS TRANSPARENTE (1958)

6. LA MUERTE DE ARTEMIO CRUZ (1962)

7. LOS AÑOS CON LAURA DÍAZ (1999)

8. LA VOLUNTAD Y LA FORTUNA (2008)

9. DOS EDUCACIONES

Las buenas conciencias (1959)

Zona sagrada (1967)

10. LOS DÍAS ENMASCARADOS

* Los días enmascarados (1954)

Constancia (1990)

Instinto de Inez (2001)

* Inquieta compañía (2004)

Carolina Grau

11. FRONTERAS DEL TIEMPO

Cantar de ciegos (1964)

La frontera de cristal (1995)

Todas las familias felices (2006)

12. EL TIEMPO POLÍTICO

La cabeza de la hidra (1978)

La silla del águila (2003)

Adán en Edén (2009)

El camino de Texas

13. CAMBIO DE PIEL (1967)

14. CRISTÓBAL NONATO (1987)

15. CRÓNICAS DE NUESTRO TIEMPO

Diana o la cazadora solitaria (1994)

Aquiles o el guerrillero y el asesino 
Prometeo o el precio de la libertad

\section{引用文献}

安藤哲行.「フエンテスを読む」.『アウラ』. Fuentes, Carlos. 安藤哲行訳. 京都, エデ イシオン・アルシーヴ, 1982, p. 201-219.

Caillois, Roger.『妖精物語から SFへ』。 三好郁郎訳. サンリオ，1978，178p.

Cano, Carlos. "La técnica narrativa de Carlos Fuentes en Aura". USF Language Quarterly. 1972, 11(1-2), p. 43-46.

Cruz, Juan. "El tiempo de Fuentes-Entrevista”. EL PAÍS.com. http://www.elpais.com/ articulo/portada/mexicanidad/Carlos/Fuentes/elpepipor/20081004elpbabese_3/ Tes, (accessed 2010-03-29).

Durán, Gloria. La magia y las brujas en la obra de Carlos Fuentes. México, UNAM, 1976, 216p.

Fuentes, Carlos. La nueva novela hispanoamericana. México, Joaquín Mortiz, 1969, $98 \mathrm{p}$.

Fuentes, Carlos. "Tlactocatzine, del jardín de Flandes”. Los días enmascarados. México, Ediciones Era, 1982, p. 34-45.

Fuentes, Carlos. "Aura”. Cuerpos y ofrendas. 4" ed., Madrid, Alianza Editorial, 1990, p. 125-159.

Fuentes, Carlos. "Cumpleaños". Cuerpos y ofrendas. 4a ed., Alianza Editorial, 1990, p. $161-230$.

Fuentes, Carlos. Geografía de la novela. México, Fondo de Cultura Económica, 1993, $178 \mathrm{p}$.

Fuentes, Carlos. "Una familia lejana". El mal del tiempo, vol. 1. Madrid, Santillana, 1994, p. 101-276.

Fuentes, Carlos. "La buena compañía”. Inquieta compañía. Madrid, Santillana, 2004, p. 81-118.

Habra, Hedy. "Modalidades especulares de desdoblamiento en Aura de Carlos Fuentes." Confluencia, 2005, 21(1), p. 182-194.

Long, Ryan. "Carlos Fuentes. Inquieta compañía.” World Literature Today, 2005, 79(2), p. 105-106.

Mead, Robert G. “Carlos Fuentes, airado novelista mexicano.” Hispania 1967, 50(2), p. 299-235.

Paz, Octavio. "La máscara y la transparencia". Cuerpos y ofrendas. Fuentes, Carlos. $4^{\mathrm{a}}$ ed., Madrid, Alianza Editorial, 1990, p. 7-15.

Paz, Octavio. La llama doble:Amor y erotismo. $2^{\text {a }}$ ed., Barcelona, Seix Barral, 1993, 
$223 p$.

Paz, Octavio. El laberinto de la soledad. 4ª ed., Madrid, Ediciones Cátedra, 1998, 578p.

Plimpton. George. ed., Writers at work: the Paris review interviews, sixth series. New York, Penguin Books, 1985, 414p.

Steinmetz, Jean-Luc. 『幻想文学』. 中島さおり訳. 白水社, 1993，159p.

Todorov, Tzvetan.『幻想文学論序説』. 三好郁郎訳。第 3 版，東京創元社，2007， 270p.

Vargas Llosa, Mario. Cartas a un joven novelista. Barcelona, Editorial Planeta, 1997, $157 \mathrm{p}$.

Williams, Raymond L. ed. Los escritos de Carlos Fuentes. México, Fondo de Cultura Económica, 1998, 230p.

\section{資料文献}

Batallie, Georges.『エロティシズム』．澁澤龍彦訳．第26版，二見書房，1993，409p.

Butor, Michel. 『心変わり』. 清水徹訳. 岩波文庫, 2005，482p.

Fuentes, Carlos.『アウラ』. 安藤哲行訳．京都，エディシオン・アルシーヴ，1982， 219p.

Fuentes, Carlos.『遠い家族』. 堀内研二訳. 現代企画室，1992，309p.

Fuentes, Carlos.『フエンテス短編集：アウラ・純な魂他四篇』。木村榮一訳，岩波文 庫, 1995, 240p.

Fuentes, Carlos. Obras Reunidas III: Imaginaciones mexicanas. México, Fondo de Cultura Económica, 2008, 710p.

Fuentes, Carlos. Adán en Edén. México, Santillana, 2009, 178p.

Carlos Fuentes Official website http://www.clubcultura.com/clubliteratura/ clubescritores/carlosfuentes/home.htm, (accessed 2010-03-29).

Hernández, George. ed., Carlos Fuentes: Territorios del tiempo, Antología de entrevistas. México, Fondo de Cultura Económica, 1999, 310p.

Paz, Octavio.「特集カルロス・フエンテス祝祭としての言語：フエンテス論一仮面と 透明性」. 木村榮一訳.『海』. 1980, 十月号, p. 321-328.

Paz, Octavio.『孤独の迷宮』. 高山智博 · 熊谷明子訳. 法政大学出版局, 1982, 311p.

Paz, Octavio.『二重の炎：愛とエロティシズム』．井上義一・木村榮一訳．岩波書店， 1997, 294p. 


\title{
Los motivos de lo fantástico en Aura de Carlos Fuentes
}

\author{
Mizuho NARITA
}

Este artículo estudia los motivos fantásticos del cuento Aura, buscando los puntos en común con otros cuentos del mexicano.

Fuentes describe en Aura otro mundo cuya idea de tiempo no es lineal enfatizando su diferencia con el mundo cotidiano. En este otro mundo Felipe experimenta la muerte simbólica a través de contacto sexual con Aura y renace al mirarse en el espejo, motivo que refleja su nueva identidad. El proceso de renacimiento está contado por el narrador desde la segunda persona gramatical con tiempo verbal futuro, lo que funciona para que la novela total tenga estructura circular.

Motivos como la invasión al otro mundo, la disolución de la identidad propia con el contacto sexual y el narrador que conduce el tiempo circular son comunes en los cuentos "fantásticos" de Fuentes, en que todo está en proceso de transfiguración y nunca se acepta el final fijo. 